\title{
Development of Tropical Cyclone over the Bay of Bengal during South West Monsoon
}

\author{
Monjila Rizwan \\ Directorate of Meteorology, Bangladesh Air Force \\ Manuscript received: 30 April 2021; accepted for publication: 31 August 2021
}

\begin{abstract}
South West Monsoon (SW Monsoon) and Tropical Cyclone (TC) are two important weather systems for Bangladesh. During SW Monsoon i.e. during rainy season Bangladesh gets $70 \%$ to $85 \%$ of her annual rainfall. TC accompanied with strong gale winds, tornadoes, torrential rains and storm surges is considered as a deadly natural disaster. TC's are mostly formed during pre-monsoon and post-monsoon season, but not uncommon during SW monsoon. This study consults the best track data (cyclone e-atlas) of India Meteorological Department (IMD) containing tracks of cyclones and depression over North Indian Ocean (NIO) for the years 1891 to 2020 i.e. of 130 years. In these 130 years, among total 1219 storms, 608 had formed during SW monsoon. If only Cyclonic Storms (CS) and Severe Cyclonic Storms (SCS) are considered then, 150 storms formed during SW Monsoon. This paper studied two cyclogenesis factors; vertical wind shear and upper level anticyclone for eight cases of tropical storms formed during SW Monsoon. Besides cyclogenesis factors, influence of Madden Julian Oscillation (MJO) is also studied. Threat analysis associated with tropical storms during SW Monsoon has been done which might help in planning of National Disaster Management Program.
\end{abstract}

Keywords: Tropical Cyclone, Cyclogenesis, South West Monsoon, Vertical Wind Shear

\section{INTRODUCTION}

South West Monsoon (SW Monsoon) and Tropical Cyclone (TC) are two important weather systems for Bangladesh vis-à-vis South Asia. The SW monsoon accounts for $70 \%$ to $85 \%$ of the annual rainfall in Bangladesh, which varies from $70 \%$ in the eastern part of the country to about $80 \%$ in the SW, and $85 \%$ in the northwest (Banglapedia, 2014). The seasonal wind of South Asia blows from the SW in summer and from the North-East (NE) in winter. The meteorological name of summer rainy season (June to September) is SW Monsoon and winter dry season (December, January and February) is NE Monsoon. The South Asian premonsoon (March-May) and post-monsoon (OctoberDecember) seasons are the transition periods between SW and NE monsoon (Ramage, 1971; Das, 1986).

TC accompanied with strong gale winds, tornadoes, torrential rains and storm surges is considered as deadly natural disaster as it causes severe destruction to human life, livestock's, property and ecosystem. Only 4\% of global TC's formed in North Indian Ocean (NIO), among them the Bay of Bengal $(\mathrm{BoB})$ experiences five to six times more cyclones than

Corresponding author: Monjila Rizwan

Email: monjila@gmail.com

DOI: https://doi.org/10.3329/dujees.v10i1.56280
Arabian Sea (Neumann, 1993). On an average, about 5-6 TC formed in the BoB every year, of which about 2 may reach to severe stage. (Sing, 2007). The BoB, located in the north of the Indian Ocean between latitude $5^{\circ} \mathrm{N}$ to $22^{\circ} \mathrm{N}$ and longitude $80^{\circ} \mathrm{E}$ to $100^{\circ} \mathrm{E}$, is roughly triangular. It is bordered by India, Bangladesh, Sri Lanka and Myanmar and extended up to the Andaman and Nicobar Islands. The BoB is not only responsible for the formation of some deadliest TC's of history; it also plays pivotal roles in the seasonal wind reversal of South Asian monsoons. Strong SW'ly wind carries enormous moist and warm air masses from the sea to the land during SW monsoon. While dry and cool NE'ly flows occur in the opposite direction, i.e. from the land to the BoB, during NE monsoon.

Though cyclones are mostly formed in transition period but not uncommon in SW monsoon. So far lot of studies and threat analysis had been carried out about TC development during pre-monsoon and post monsoon season but very less discussed about TC of SW monsoon. This study consults Best Track Data (cyclone e-atlas) of India Meteorological Department (IMD) containing data and tracks of cyclones and depression over NIO for the years 1891 to 2020 i.e. 130 years. In this paper attempt has been made to find out the trend of $\mathrm{TC}$ development in $\mathrm{BoB}$ and reason of cyclogenesis during SW Monsoon. 
Six factors are considered favorable for the formation of a TC (Asnani, 1993). Which are:

a. Vicinity of ITCZ or near-equatorial trough.

b. Sea surface temperature $\geq 27^{\circ} \mathrm{C}$.

c. Arrival of an easterly wave.

d. Ahead of an upper air trough favouring upper-level divergence.

e. Weak vertical shear of wind, less than $10 \mathrm{~ms}^{-1}$ between 950 and $200 \mathrm{mb}$.

f. Some distance (at least $3^{\circ}$ latitude) away from the equator.

Besides these factors, some other factors like lower tropospheric relative vorticity, 24 hours pressure fall are also considered important by the scientists (Gray, 1968; Dvorak, 1975; Zehr, 1992). Vertical wind shear remains very strong particularly over the Arabian Sea and $\mathrm{BoB}$ during the SW Monsoon season. However this is a major factor that limits the synoptic scale disturbances from intensifying into TC during this season (Rao, 1976).

Monsoon Depressions (MD) over the period of 1891 to 2010 clearly shows a decreasing trend in the frequency after 1950s, which is significant at $99 \%$ confidence level (Mann-Kendall test). After 1985, the mean frequency of $\mathrm{MD}$ reduces to 2-3 depression/season (Prajeesh et al., 2013). On the other hand a significant increasing trend in the June, July, August and September (JJAS) mean Sea surface
Temperature (SST), averaged over BoB since 1950s (Prajeesh et al., 2013). So this rule out the role of the SST in the falling frequency of the MD's over BoB. The trend of frequency of tropical disturbances (D, CS and SCS) also shows a decreasing trend during SW monsoon season in $95 \%$ statistical confidence level (Malik et al., 2016).

The Madden-Julian Oscillation (MJO) is the eastward moving 'pulse' of cloud and rainfall near the equator that typically recurs every 30 to 60 days. TC genesis favorably occurred during the convective phase of MJO (Krishnamohan et al., 2012). This accounted for 44 cyclones of the total 54 cyclones (i.e. 81.5\%) formed under MJO amplitude 1 and above. It is found that when the enhanced convection of MJO is over the maritime continent and the adjoining Eastern Indian Ocean, it creates the highest favorable environment for cyclogenesis in the BoB.

Cyclone forecast is very important as with the forecast and early warning, disaster preparedness started. Bangladesh had experienced some of the deadliest cyclones of world history. But by taking required preparedness, in spite of occurrence of potential severe cyclone in recent the death toll reduced significantly and Bangladesh is today considered as a world leader in cyclone resilience. In this paper some threats associated with SW monsoonal cyclone are analyzed with examples, so that appropriate preparation measures can be planned by considering the threat types.

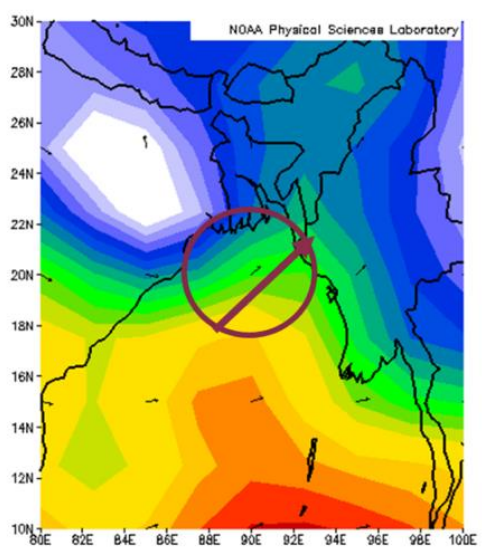

(a) Mean Wind of $850 \mathrm{mbs}$

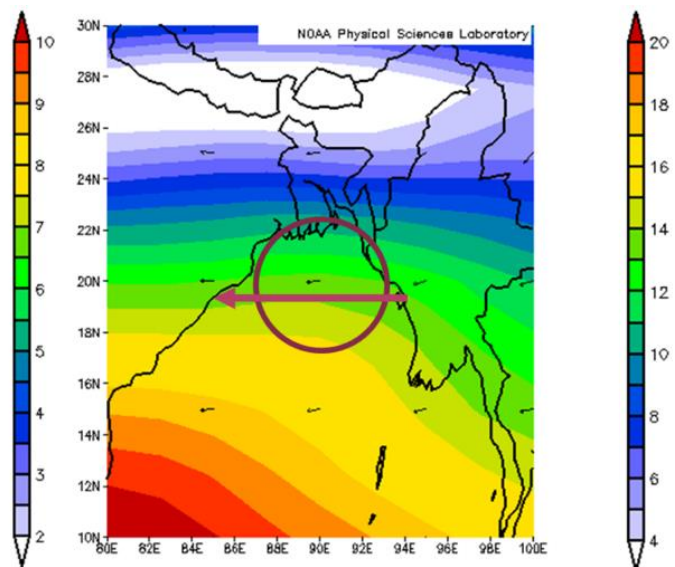

(b) Mean Wind of $200 \mathrm{mbs}$

Figure 1: Mean Wind of $850 \mathrm{mbs}$ and $200 \mathrm{mbs}$ for the Months June to September Source: https://psl.noaa.gov/cgi-bin/data/composites/printpage.pl 


\section{DATA AND METHODOLOGY}

To analyze the trend, frequency and track of tropical storms over BoB this paper used the 130 years (1891 to 2020) Best Track (cyclone e-atlas) data and Bulletin of India Meteorological Department (IMD). Vector Wind of $850 \mathrm{mbs}$ and $200 \mathrm{mbs}$ of area $10^{\circ} \mathrm{N}$ to $30^{\circ} \mathrm{N}$ and $80^{\circ} \mathrm{E}$ to $100^{\circ} \mathrm{E}$ is analyzed by using NCEP Operational plotting tools of NOAA Physical Science Laboratory. During SW Monsoon (June to September) the mean wind is SW'ly at $850 \mathrm{mbs}$ and E'ly at $200 \mathrm{mbs}$. Vertical wind shear between $850 \mathrm{mbs}$ and $200 \mathrm{mbs}$ is calculated by vector addition/Hodograph. Online interactive tool (https://courseware.e-education.psu.edu/) is used for this purpose (Figure 1). MJO phases are analyzed by using MJO phaWse diagram of Bureau of Meteorology, Australian Government. The rainfall and wind data of Bangladesh Air Force, Meteorological Squadrons are also used as supportive data.

This paper analyzed four occurrence cases of TC and four cases of non-occurrence cases of TC i.e. tried to find why a storm of D/Deep Depression (DD) strength had not turned into CS. Though the difference between DD and CS is insignificant. As per the IMD defined category of tropical storms, for DD associated three minutes sustained wind speed range is $28-33$ knots and for CS it is 34-47 knots. From 2001 to 2020 only three CS formed over BoB and those three taken for occurrence case studies. Besides these, SCS of 1997 is also studied. For non-occurrence case studies DD of 2-5 July 2006, and DD of 4-7 September 2009, DD of 10-13 June 2017 and D of 10 and 11 June 2018; these four cases are taken.

\section{DISCUSSION}

\section{Trend Analysis of Tropical Storms over BOB}

From 1891 to 2020, in these 130 years total 1219 tropical storms i.e. D, DD, CS and SCS formed over BoB (Table 1). Among these storms 608 formed during SW Monsoon season and among these 608 storms, 150 turned into CS intensity. Again from 1891 to 1900 in this 10 years 28 , from 1901 to 1950 in this 50 years 85 , from 1951 to 2000 in this 50 years 34 and 2001 to 2020 in this 20 years only 3 TC formed over BoB. So, it is evident that frequency of TC over BoB is declining. Not only $\mathrm{TC}$, the trend of Tropical storms development over BoB is declining. The numbers of storms over $\mathrm{BoB}$ in different time frame as well as tracks Of cyclonic storms and severe cyclonic storms for the period $1891-2020$ are shown in Figure 2.

Table 1: Number Distribution of Tropical Storms Formed over BoB in Last 130 years

\begin{tabular}{|l|c|c|c|c|c|c|}
\hline Time Frame & \multicolumn{2}{|c|}{$\mathrm{D}+\mathrm{DD}+\mathrm{CS}+\mathrm{SCS}$} & \multicolumn{2}{c|}{ CS+SCS } & \multicolumn{2}{c|}{ SCS } \\
\cline { 2 - 7 } & Number & Frequency/Year & Number & Frequency/Year & Number & Frequency/Year \\
\hline $\begin{array}{l}1891-2020 \\
\text { (Jan-Dec) }\end{array}$ & 1219 & 9.42 & 524 & 4.03 & 237 & 1.82 \\
\hline $\begin{array}{l}1891-2020 \\
\text { (Jun-Sep) }\end{array}$ & 608 & 4.67 & 150 & 1.16 & 31 & 0.24 \\
\hline $\begin{array}{l}1891-1900 \\
\text { (Jun-Sep) }\end{array}$ & 61 & $\mathbf{6 . 1}$ & 28 & $\mathbf{2 . 8}$ & 6 & $\mathbf{0 . 6}$ \\
\hline $\begin{array}{l}1901-1950 \\
\text { (Jun-Sep) }\end{array}$ & 293 & $\mathbf{5 . 8 6}$ & 85 & $\mathbf{1 . 7}$ & 15 & $\mathbf{0 . 3}$ \\
\hline $\begin{array}{l}1951-2000 \\
\text { (Jun-Sep) }\end{array}$ & 218 & $\mathbf{4 . 3 6}$ & 34 & $\mathbf{0 . 6 8}$ & 10 & $\mathbf{0 . 2}$ \\
\hline $\begin{array}{l}\text { 2001-2020 } \\
\text { (Jun-Sep) }\end{array}$ & 36 & $\mathbf{1 . 8}$ & 3 & $\mathbf{0 . 1 5}$ & -- & -- \\
\hline
\end{tabular}

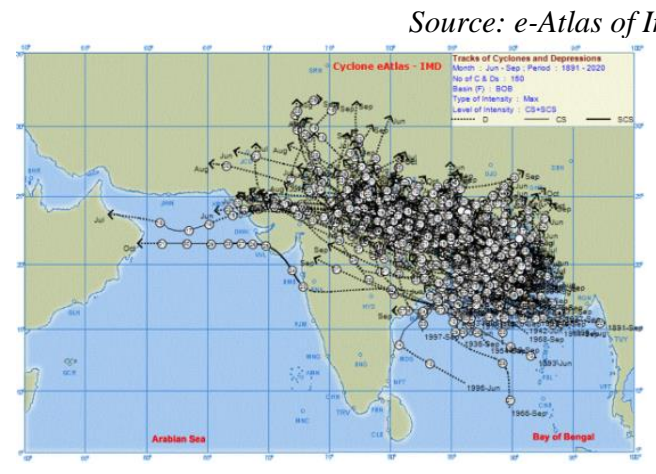

(a)

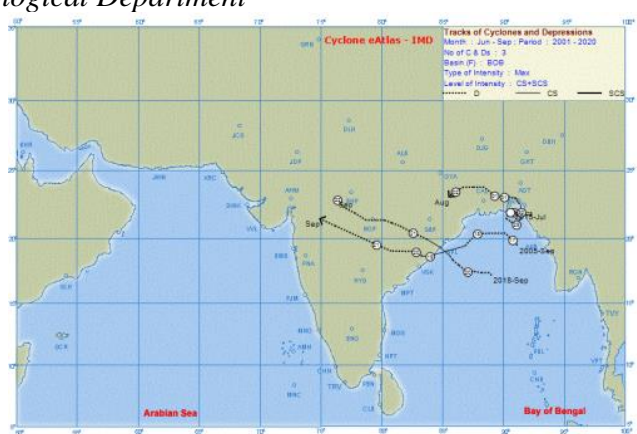

(b)

Figure 2: Tracks of Cyclonic Storms and severe cyclonic storms for the period (a) 1891-2020 (b) 2001-2020 Source: Figures are generated by online e-Atlas of India Met Department 


\section{CASE STUDIES: OCCURENCES}

\section{Case 1: SCS of 97 (19- 27 September 1997)}

Meteorological History: On 19 September 1997, a $\mathrm{D}$ formed from an area of disturbed weather in the west BoB. It gradually travelled NW'ward i.e. towards the Indian coastline, but due to effect of mid-latitude trough it re-curved NE'ward, The D intensified into DD on the 24th, and it reached TC strength while tracking paralleling the Indian coastline on 26th. It made landfall through Bangladesh coast on the 27th, and dissipated shortly thereafter. The SCS was responsible for 51 fatalities and left an additional 137 people missing.

Analysis of Vertical Wind Shear and Position of Anticyclone: In the initial stage moderate vertical wind shear observed in between $850 \mathrm{mbs}$ to $200 \mathrm{mbs}$ from 19-23 September. On $24^{\text {th }}$ vertical wind shear was weak and the system also intensified into DD and then CS. Till landfall on $27^{\text {th }}$ the vertical wind shear was weak over N BoB. Upper air anticyclone was observed towards E-SE of the storm.

MJO Analysis: From 20-27 September the MJO was in phase 3 i.e. favors convection in Indian Ocean region visà-vis BoB region. So MJO was favorable for intensification of the system from D to SCS.

\section{Case 2: TC Pyarr (17- 21 September 2005)}

Meteorological History: On 15 September 2005 a remnant of D from South China Sea emerged into the northern Andaman Sea as a Low Pressure Area. It moved northward and on 17 September over East Central (EC) BoB and adjoining NE Bay it concentrated into D. On the next day, the system intensified into a DD and later CS, whereupon the IMD named it Pyarr. Attaining peak winds of $65 \mathrm{~km} / \mathrm{h}$ (40 mph), the storm took an unusual track to the SW. On 19 September, Pyarr made landfall just NE of Kalingapatnam in Andhra Pradesh. It turned westward and weakened over land, deteriorating into a remnant low on 22 Sep 05 over Madhya Pradesh.

Analysis of Vertical Wind Shear and Position of Anticyclone: Except 16, from 15 to 19 September weak vertical wind shear observed in between $850 \mathrm{mbs}$ to $200 \mathrm{mbs}$ over $\mathrm{N} \mathrm{BoB}$ and Central $\mathrm{BoB}$ which favors intensification of TC Pyarr. Throughout the period upper air anticyclone was observed towards east of the storm.
MJO Analysis: During TC Pyarr, the MJO was in phase 6,7 8. ie in these phases suppressed convection was in Indian Ocean region. So MJO was not favorable for intensification of TC Pyarr.

\section{Case-3: TC Komen (26 July- 02 August 2015)}

Meteorological History: The CS Komen is an exceptional and unique example of TC that occurred over N BoB in 2015 during SW Monsoon. On 25 July, a Low-Pressure Area formed over Southern coast of Bangladesh and adjoining $\mathrm{N}$ BoB over the monsoon axis. On the morning of $26^{\text {th }} \mathrm{July}$, the low concentrated into $\mathrm{D}$ and remained almost stationary over the water body near coastal area for two days. At midnight of 28 July the D intensified into DD and moved over NE BoB where it had made a unique semi-circular track. On 29 July, early morning Joint Typhoon Warning Centre (JTWC) termed the system as TC, named Komen. On 29 July evening Komen attained peak 1-minute sustained wind of $75 \mathrm{~km} / \mathrm{h}$ (39 Kts/ $45 \mathrm{mph}$ ), based on estimates from satellite imagery. During the night of $29^{\text {th }}$ July between $1400-1500$ UTC, Komen made landfall on Bangladesh through NW Chattogram. Komen quickly weakened into DD as it turned towards NW across Bangladesh, steered by a ridge of Tibetan High. On 31 July, the system entered into the Indian state of West Bengal as a weak Depression. The track shifted to the W-SW until Komen weakened into a remnant low on $2^{\text {nd }}$ August over Jharkhand.

Analysis of Vertical Wind Shear and Position of Anticyclone: Weak vertical wind shear of 4 to $8 \mathrm{~m} / \mathrm{s}$ is observed over southern coast of Bangladesh and adjoining NE BoB from 25- 27 July, which helps the land low to turn into D and thereafter into DD. However at $200 \mathrm{hPa}$ upper level anticyclone observed over south coast of Bangladesh and adjoining North BoB which favored further intensification of the system.

MJO Analysis: During TC Komen i.e. 25 July to 02 August, the MJO was in phase 2 and 1, so not favored in the development of the system.

\section{Case-4: TC Daye (19 - 22 September 2018)}

Meteorological History: On 19 September 2018, a $\mathrm{D}$ formed over the East Central (EC) BoB. The system had been moving towards NW and early on 20 September, the storm intensified into a DD over West Central (WC) Bay. The system intensified further into CS Daye later that day. Early on September 21, Daye 
made landfall on south Odisha, also impacting the adjoining North Andhra Pradesh coast near Gopalpur, during the morning, resulting in heavy rains and strong winds of 65 to $75 \mathrm{~km} / \mathrm{h}$ in the regions. Upon its landfall, Daye brought heavy to very heavy rainfall in various districts of Odisha. Following landfall, the CS weakened into D. Over the next two days, Daye continued moving westward, while dropping heavy amounts of rain across India. The outer rain bands of the storm dropped extremely heavy rain in the southern parts of West Bengal. Torrential rains and flash floods were also reported in Himachal Pradesh, Uttarakhand, and Punjab, resulting in at least 25 deaths.

Analysis of Vertical Wind Shear and Position of Anticyclone: Strong vertical wind shear was observed between $850 \mathrm{hPa}$ to $200 \mathrm{hPa}$ which was unfavorable for intensification of the system. Only the presence of upper level (at $200 \mathrm{hPa}$ ) ridge at $\mathrm{NE}$ of the system favored further intensification of the system.

MJO Analysis: During TC Daye ie 19 to 21 September 2018, the MJO was in phase 2 and 3. So phase 3 of MJO enhanced convection and favored further development of the system.

\section{CASE STUDIES: NON-OCCURENCES}

\section{Case 1: DD over BoB (02 - 05 July 2006)}

Meteorological History: In last week of June, an unusual area of disturbed weather persisted over the $\mathrm{N}$ $\mathrm{BoB}$. A low pressure area eventually formed over $\mathrm{N} \mathrm{BoB}$ and instead of strong vertical wind shear, the system rapidly organized into a DD by $2^{\text {nd }}$ July. The weak steering currents slowly drove the system towards west. The DD made landfall between Paradeep and Chandabali in Odisha. The DD produced heavy rains across a large area of India and Bangladesh.

Analysis of Vertical Wind Shear and Position of Anticyclone: Moderate to Strong vertical wind shear observed in between $850 \mathrm{mbs}$ to $200 \mathrm{mbs}$ during 02 to 05 July over N Bay and adjoining coastal areas. Due to other cyclogenesis factors though the system organized into DD but strong vertical wind shear and absence of upper level anticyclone might not favor the storm to intensify further.

MJO Analysis: During first week of July 2006 the MJO was in phase 7. So MJO phase had suppressed convection over Indian Ocean and had not favored further development of the system.

\section{Case 2: DD over BoB (05 - 07 September 2009)}

Meteorological History: An area of Low-Pressure area formed over NW BoB near Odisha coast. The next day it developed further and had become Well Marked Low (WML) with deep convection. Early on 5 September, the WML intensified into a D. Later that day the IMD reported that the $\mathrm{D}$ had intensified further and had become a DD, though the JTWC designated the storm as a TC $03 \mathrm{~B}$, as winds equivalent to a tropical storm. However the DD had made landfall near Digha in West Bengal on $6^{\text {th }}$ afternoon. However, the IMD kept issuing advisories on the DD until early on September 7, when the IMD reported that it had weakened into a D and then into a WML later that day.

Analysis of Vertical Wind Shear and Position of Anticyclone: 4-7 September 2009 vertical wind Shear was weak over NW BoB and adj Gangetic West Bengal. Moreover, no specific upper level anticyclone or divergence seen over the area.

MJO Analysis: During first week of September 2009 the MJO was in phase 4. So MJO phase had enhanced convection over BoB and had favored the system to get the strength of DD.

\section{Case-3: DD over BoB (10-13 June 2017)}

Meteorological History: On 10 June morning, a low pressure area formed over west central \& adjoining $\mathrm{N} \quad$ BoB off north Andhra Pradesh and south Odisha coast. It concentrated into a WML over central $\mathrm{BoB} \&$ adjoining $\mathrm{N} \mathrm{BoB}$ on $11^{\text {th }}$ June morning and concentrated into a D over N BoB in the evening. An anti-cyclonic circulation lay to the SE of the system favored further intensification of the system. While moving nearly N-NE'wards, it intensified into a DD over $\mathrm{N}$ BoB in the night of $11^{\text {th }}$ (1800 UTC). Moving N-NE'wards, it crossed Bangladesh coast near Khepupara between 2300 UTC of $11^{\text {th }}$ and 0000 UTC of $12^{\text {th }}$ June. As the system moved over land, it weakened gradually into a D over east Bangladesh \& neighborhood due to land surface interaction and thereafter into a well-marked low pressure area.

Analysis of Vertical Wind Shear and Position of Anticyclone: Only on $11^{\text {th }}$ June, weak vertical wind shear observed in between $850 \mathrm{mbs}$ to $200 \mathrm{mbs}$ over $\mathrm{N}$ Bay and adjoining area. However, on $10^{\text {th }}, 12^{\text {th }}$ and $13^{\text {th }}$ June vertical wind shear was strong over that area. An anti-cyclonic circulation observed over $\mathrm{N}$ BoB during the period. 
MJO Analysis: During the period of DD i.e. 10-13 June 2017, MJO was in phase 8 and 1. In those phases convection over Indian Ocean region was suppressed.

\section{Case-4: D over BoB (10-11 June 2018)}

Meteorological History: In 2018 SW Monsoon set over BOB and Eastern part of Bangladesh by $6^{\text {th }}$ June. With active monsoon conditions, a low pressure area formed over $\mathrm{N} \mathrm{BoB}$ and neighborhood in the evening (1200 UTC) of 08 June. It remained as WML over NE BoB and adjoining Bangladesh in the morning (0300 UTC) of 10 June. It concentrated into a D around noon (0600 UTC) of $10^{\text {th }}$ June over NE BoB and adjoining Bangladesh. It tracked nearly N-NW' wards and crossed Bangladesh coast through Feni at night (around 1500 UTC) of 10th June and weakened into a WML in the early morning (0000 UTC) of 11 June. The system caused heavy rainfall over southern coast of Bangladesh and at isolated places over Gangetic West Bengal, Odisha and Jharkhand on $9^{\text {th }}$. On 10 June $318 \mathrm{~mm}$ rainfall recorded over Chattogram (BAF Base Zahurul Hauque) with max wind speed 60Kts during landfall time of the system (24060Kts).

Vertical Wind Shear and Position of Anticyclone: From 09-11 June 2018, weak vertical wind shear observed in between $850 \mathrm{mbs}$ to $200 \mathrm{mbs}$ over NE Bay and adjoining SE coast of Bangladesh, which helped the short lived storm intensify very quickly.

MJO Analysis: During the period of Depression, 10-11 June 2018, MJO was in phase 5 which suppressed the convection of the system.

\section{RESULT OF CASE STUDIES}

In the eight case studies vertical wind shear over the storm area, Position of upper level anticyclone and MJO phases are analyzed. The findings from the case studies are appended Table 2.
THREAT ANALYSIS OF TROPICAL CYCLONE HAZARDS DURING SW MONSOON

Bangladesh is vulnerable to variety of natural disasters such as cyclones, thunderstorms, tornadoes, hailstorms, heat and cold waves, floods, droughts, landslides, earthquakes etc. TC is such a hazard which is accompanied by other natural hazards like storm surge, flood, landslide, torrential rain and tornadoes along with gale wind. Some hazards associated with tropical storms during SW monsoon and their destruction are discussed here.

Torrential Rain: Torrential rain is the main characteristics of CS developed during SW monsoon. Due to presence of deep layer of moisture whenever any cyclonic system developed over BoB in this monsoon season, deep convection and cloud generation started over the area. Continuous downpour from enormous cloud can cause flood and water logging in plain area, flash flood and land slide in hilly areas. Continuous rainfall made the soil of hill areas soft and can create landslide.

Flash Flood and Landslide: TC Komen (26 July -02 August 2015): TC Komen is one of most exceptional, abnormal and unique cyclone ever developed in BOB. From the initial stage of the storm, the coastal areas of Bangladesh experienced strong wind. 23 July to 02 August and in 10 days Chattogram had $1212 \mathrm{~mm}$ rainfall. Much of SE Bangladesh saw repeated heavy rainfall on a daily basis. The results were fatal, even though about 5 lac people were evacuated before landfall of TC Komen. Media reports indicated at least 28 people have died from stormcaused flash flood and landslide in Bangladesh. According to the Bangladesh Daily Star five people died in a landslide in Cox's Bazar on 27 July following a flashflood and four others were pulled from the mud alive.

Table 2: Result of Case Studies for Occurrence and Non-Occurrence of TC over BoB

\begin{tabular}{|l|l|l|l|l|l|l|l|l|}
\hline & SCS,97 & TC Pyarr & TC Komen & $\begin{array}{l}\text { TC } \\
\text { Daye }\end{array}$ & $\begin{array}{l}\text { DD } \\
\text { Jul 06 }\end{array}$ & $\begin{array}{l}\text { DD } \\
\text { Sep 09 }\end{array}$ & $\begin{array}{l}\text { DD } \\
\text { Jun 17 }\end{array}$ & $\begin{array}{l}\text { D } \\
\text { Jun 18 }\end{array}$ \\
\hline $\begin{array}{l}\text { Vertical } \\
\text { Wind Shear }\end{array}$ & Weak & Weak & Weak & Strong & $\begin{array}{l}\text { Moderate } \\
\text { to Strong }\end{array}$ & weak & weak & weak \\
\hline $\begin{array}{l}\text { Upper Level } \\
\text { Anticyclone }\end{array}$ & $\begin{array}{l}\text { Towards } \\
\text { E-SE }\end{array}$ & Towards E & $\begin{array}{l}\text { Towards } \\
\text { NW }\end{array}$ & $\begin{array}{l}\text { Ridge } \\
\text { towards N }\end{array}$ & -- & -- & Ridge & Over D \\
\hline MJO & 3 & $6,7 \& 8$ & $2 \& 1$ & $2 \& 3$ & 7 & 4 & $8 \& 1$ & 5 \\
\hline
\end{tabular}


Flash Flood and Landslide: DD (10-13 June

2017): The landslide of June 2017 is one of the fatal disasters in the SE hill tracts. At least 156 people had been confirmed dead following flash flood and landslides in Rangamati, Bandarban and Chattogram districts of Bangladesh along with 14 others in NE India caused by torrential rainfall. More than $400 \mathrm{~mm}$ rainfall recorded at Chattogram, $500 \mathrm{~mm}$ in Rangamati while Cherrapunji received $320 \mathrm{~mm}$ rain in association with the system. The system helped in the advancement of monsoon over the regions of West Bengal and Odisha. Damages included loss of Tk. 18 billion.

Storm Surge: It is one of the disasters associated with TC that cause fatalities and mass destruction. The triangular shape of Head Bay helps to funnel the sea water pushed by the wind towards the coast and causes further modification of the surge. During SW monsoon time a large volume of water discharges through the Meghna estuary and other distributary channels. This non-saline water when mixed with the saline water of the BOB, causes an increase of the volume of the water; and consequently the tidal amplitudes are increased. The Tide Book of BIWTA shows an increase of tidal height above the normal height between $50 \mathrm{~cm}$ to 100 $\mathrm{cm}$ during the $\mathrm{SW}$ monsoon period. Maximum tide height in Full Moon and New Moon phases for different months of 2020 is appended below:

When the high tide coincides with the storm surge, the impact becomes severe, especially around the estuary. Tide and surges are not linearly additive but interactive. This means that if, for example, a $5 \mathrm{~m}$ surge is superimposed on a $5 \mathrm{~m}$ tide, the total height will not be $10 \mathrm{~m}$. Tides modify the surge amplification. In Bangladesh Surge height strongly dependent on the cyclone track. Storm surges are usually highest to the right (looking down the direction of the cyclone motion) of the track as the maximum wind speed also observed to the right or SW quadrant of the track. When a cyclone approaches the land to the north, this wind tends to pile up water against the coast. This tendency is reinforced by the shallow water and convergence effects. The effect of all these factors is to produce even a higher positive surge to the right of the cyclone path or point of landfall. Wind on the left (in the off-shore direction) drives water away from the coast and produces a negative surge. The Multi-purpose Cyclone Shelter project (MCSP) in Bangladesh prepared a table which shows surge inundation characteristics for cyclones of varying strength in Bangladesh. This Table is prepared without considering the effect of new moon, full moon and monsoonal tide height. So, when tropical storms of SW Monsoon landfall time coincide with new or full moon high tide time the limit of inundation as per the MCSP prepared Table might be crossed. However, maximum high tide height of Khal No-10 (as an example) during new moon and full moon for 2020 is shown in Table 3. Tropical storms of SW monsoon seldom cause storm surge. However, example of storm surge associated with CS during SW monsoon is appended below.

Storm Surge during TC Pyarr (17-22 September 2005): As $D$, the system produced damaging swells along coastal Bangladesh, forcing 12,000 people to evacuate. Torrential rainfall affected eastern coastal India, with a daily peak of $490 \mathrm{~mm}$ (19 in) in Kunavaram. The rains caused rivers to rise, forcing 36,000 people to evacuate after 315 villages were affected. Pyarr also ruined 482,188 ha (1,191,510 acres) of crop fields, hatcheries and fisheries. In Andhra Pradesh, the storm damaged 12,041 houses, with overall damage estimated at Rupee 503 million. More than 140,000 people were forced to relocate after the Godavari and Krishna rivers burst their banks and caused tremendous flooding. At least 64 people died across Andhra Pradesh and Odisha.

Table 3: Maximum High Tide Height of Khal No-10 during New Moon and Full Moon

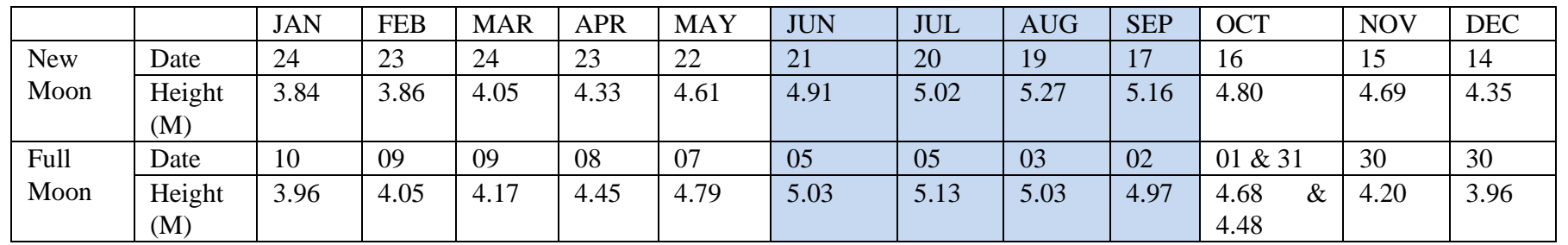

Source: Tide Table for 2020, BIWTA, Department of Hydrography, Dhaka

Gale Wind: Gale wind or Gale Force wind is 10 minutes averaged surface wind speed of 34 to 47 knots
(62 to $87 \mathrm{~km}$ per hour or wind force of 8 or 9 in the Beaufort Scale). Gale wind is capable of structural 
damage, uproot trees and can produce moderate high (13 feet or more) wave. During SW monsoon few storms can attain the gale force. In last 20 years 3 storms attained the strength of CSt which were associated with 3 minutes sustained wind of $35 \mathrm{kts}$ or more. However, during Depression of June 2018, 60 Kts gusty wind recorded over Petagna, Chattogram (Bangladesh Air Force Base Zahurul Haque).

\section{SUMMARY AND CONCLUSION}

Understanding of genesis, track and intensification of tropical storms is important for TC forecasting and associated disaster preparedness. In last 130 years significant environmental changes occurred in $\mathrm{BoB}$, so as in frequency and characteristics of CS. The salient findings of this paper are appended below.

a. The Frequency of TC over BoB during SW monsoon shows decreasing trend and only $3 \mathrm{TC}$ developed over BoB in last 20 years. During last 130 years total 1219 storms developed over BoB. Among the 1219 storms, 608 i.e. 50\% storms formed during SW monsoon and among the 608, 150 i.e. $24.67 \%$ turned into TC during SW monsoon. The frequency of TC per year is 2.8 in $1891-1900$ period, 1.7 in 1901-1950 period, 0.68 in 1951-2000 period and only 0.15 in 2001-2019 period. So trend of development of TC during SW monsoon is declining.

b. In last 130 years 31 storms of intensity equal to or more than SCS formed over BoB and it also shows decreasing trend. After 1997 no cyclone of category SCS strength developed over BoB during SW Monsoon.

c. Among the four TC studied in the paper, MJO were unfavorable situation during TC Pyarr and TC Komen. In case of SCS of 97 and TC Daye MJO favored convective development over BoB. So favorable MJO phase with other favorable cyclogenesis condition may help any storm in further intensification.

d. TC Pyarr and TC Komen followed an abnormal track i.e. moved equator ward or towards south in some portion of their life.

e. Except TC Daye, during other three TC development, weak vertical wind shear was observed over storm area in between $850 \mathrm{mbs}$ and $200 \mathrm{mbs}$. Except DD of July 2006 in other three DD and D, weak vertical wind shear observed. So it is evident that weak vertical wind shear plays an important role in intensification of tropical storm during this season.

f. TC and D developed during SW monsoon seldom cause severe storm surge and coastal flood. However, as high tide height remains more during SW Monsoon season, if landfall of any storm happen during new moon or full moon time and merged with high tide time, than low lying coastal areas will surely be flooded by the storm surge.

g. Storm surge in coastal areas, flash flood in hilly areas and flood \& water logging in plain land in SW monsoon destroys standing crops, fisheries and hatcheries over thousands of acres land. Storm surge associated with cyclonic storm or gale force wind often become destructive as beside human casualties as it damages houses, killed livestock.

Bangladesh is an agricultural country. Again, the agriculture of this country greatly depends on monsoonal rainfall. This rain becomes curse for the poor farmers when it associated with the tropical storms. During monsoon the rivers, ponds, lakes and other water bodies remain saturated. So, even continuous moderate rain for several days can cause flood or water logging situation. The effect of tropical storms in SW monsoon not limited to coastal areas only. The steering wind can take the rain from BoB to Cherapunji, even to Arabian Sea or Himachal Pradesh.

Bangladesh is one of the world's fastest growing economies and also one of the most disaster-prone countries in the world. Disaster risk reduction is essential for sustainable development. However occurrence of natural disaster cannot be stopped or controlled. But the destruction caused by natural disaster can be controlled or minimized by taking appropriate and timely actions. Since the super cyclone of 1991, which killed more than 135,000 people and caused billion-dollars damage, lot of actions are taken by government of Bangladesh. Organization like Cyclone Preparedness Program and Disaster Management Bureau are established. The preparedness actions are well paid off. The death tolls and damages by TC's are declining. By the Super Cyclone Amphan, which is one of the recent strongest tropical storms over $\mathrm{BoB}, 20$ people died and estimated damage is around 130 USD. This is a definite development in saving lives and property. Definitely accurate forecasting and early 
waning played an important role in the disaster preparedness and management.

Acknowledgement: The paper is based on the presentation made in the International Conference on Meteorology and Climate Science 2020 organized by Department of Meteorology, University of Dhaka. Dr. Dewan Abdul Quadir is gratefully thanked for his guidelines. Met Branch, Bangladesh Air Force is also thankfully acknowledged for all supports.

\section{REFERENCES}

Asnani G. C. (2006). Tropical Meteorology. Royal Meteorological Society.doi.org/10.1002/ qj. 49712051917. 237-239

Bangladesh Tide Table. (2020). Department of Hydrography. BIWTA. Dhaka. 19-24.

Banglapedia (2014). Climate (http://en.banglapedia.org/ index.php?title=Climate). (Accessed 2020-10-11).

Cyclone-e-Atlas, India Met Department. (http://14.139.191. 203/ ViewByParam. aspx). (Accessed 2020-10-10).

Das. P. K. (1986). Monsoons. WMO Paper No. 613. World Meteorological Organization. Geneva.

Dvorak, V. (1975): Tropical cyclone intensity analysis and forecasting. Mon. Wea. Rev.103: 420-430.

Flood List. (2020). http://floodlist.com/asia/bangladeshlandslides-chittagong-june-2017 (Accessed 2020-10-11).

Gray, W. M. (1968). Global view of the origin of tropical disturbances and storms. Mon. Wea. Rev, 96: 669-700.

Gray, M.W. (1990). Tropical cyclone formation. Proceedings of the Second WMO International Workshop on Tropical Cyclones (IWTC-II), Manila, Philippines, 27 November to 8 December, 1989.

Interactive Tool for Calculating Vertical Wind Shear https://courseware.e-education.psu.edu/courses/ meteo361/javascript/Lesson3/shear_calc.html\#.
Krishna. K. M. (2009). Intensifying tropical cyclones over the North Indian Ocean during summer monsoon Global warming. Research Gate. DOI: 10.1016/j. gloplacha. 2008.10.007.

Mallik, C., Ahasan, A. and Hasan, M. (2016). Seasonal and Annual Trend of Cyclonic Disturbances over the BoB. Research Gate. DOI: 10.9790/4861-0804026877.

NCEP Operational Dataset, NOAA Physical Science Laboratory. (https://psl.noaa.gov/ data/ histdata/). (Accessed 2020-10-01).

Monthly/seasonal Climate Composites. Physical Science Laboratory. (https://psl.noaa.gov/ cgi-bin/ data/ composites/ printpage.pl). (Accessed 2020-10-01).

Prajeesh, A. and Bhaskar R. (2013). Falling monsoon depression frequency: A Gray-Sikka conditions perspective. (https://www.nature.com/ articles/ srep 02989) (Accessed 2020-10-01)

Rajeevan, P. (2000). Decadal variation of sea surface temperatures, cloudiness and monsoon depressions in the north Indian Ocean. Research Gate. Current science 79(3):283-285.

Ramage, C. S. (1971). Monsoon Meteorology, Academic Press, New York.

Ramsay, H. (2017). The Global Climatology of Tropical Cyclones. Oxford research Encyclopedia. doi.org/10.1093/acrefore/9780199389407.013.79.

Rao. Y.P. (2009). Southwest Monsoon. India Meteorological Department.

Sing. O.P., (2006). Long-term trends in the frequency of severe cyclones of Bay of Bengal: Observations and simulations. Mausam 551.515.2 (267.64). 60. 